\title{
Pengaruh Citra Toko dan Persepsi Harga terhadap Niat Beli Ulang dengan Citra Produk Private Label sebagai Variabel Mediasi (Studi Empiris pada Hypermart dan Indomaret di Kota Pontianak)
}

\author{
Rony Jusfarani a, Barkah b, Wenny c \\ *abc Magister Manajemen Fakultas Ekonomi dan Bisnis, Universitas Tanjungpura, \\ Pontianak, Indonesia \\ *Email : rony jusfarani@yahoo.com \\ (Diterima Oktober 2019; Disetujui Februari 2020; Dipublikasikan April 2020)
}

\begin{abstract}
Abstrak
Niat beli ulang merupakan salah satu faktor penting bagi perusahaan. Niat beli ulang terhadap suatu produk tersebut timbul karena konsumen merasa puas akan produk yang dibeli sebelumnya. Tujuan dari penelitian ini adalah untuk mengetahui pengaruh citra toko, persepsi harga dan citra produk private label terhadap niat beli ulang pada Hypermart dan Indomaret Kota Pontianak. Pengumpulan data dilakukan dengan menyebarkan kuesioner yang berisikan pernyataan dengan jumlah responden sebanyak 60 orang pada Hypermart dan 60 orang pada Indomaret. Teknik pengambilan sampel menggunakan metode non-probability sampling berupa purposive sampling. Data dari hasil pengumpulan kuesioner diolah dengan menggunakan uji validitas, uji reliabilitas, uji asumsi klasik dan analisis jalur (path analysis).

Hasil penelitian menunjukkan: 1) Citra toko dan persepsi harga berpengaruh signifikan terhadap citra produk private label pelanggan Hypermart. 2) Citra toko dan persepsi harga berpengaruh signifikan terhadap niat beli ulang pelanggan Hypermart. 3) Citra produk private label berpengaruh signifikan terhadap niat beli ulang pelanggan Hypermart. 4) Citra toko dan persepsi harga berpengaruh signifikan terhadap citra produk private label pelanggan Indomaret. 5) Citra toko dan persepsi harga berpengaruh signifikan terhadap niat beli ulang pelanggan Indomaret. 6) Citra produk private label tidak berpengaruh terhadap niat beli ulang pelanggan Indomaret.
\end{abstract}

Kata kunci: Citra toko, persepsi harga, citra produk private label dan niat beli ulang

\section{PENDAHULUAN}

Seiring berjalannya waktu dan arus modernisasi, perkembangan bisnis ritel modern beberapa tahun terakhir sangatlah pesat. Ritel modern muncul karena peritel melihat peluang dari adanya kebutuhan masyarakat yang belum terpenuhi. Munculnya berbagai macam gerai ritel modern menyebabkan tingkat persaingan menjadi tinggi. Salah satunya yang terjadi pada persaingan peritel internasional, yaitu raksasa ritel dunia asal Amerika Serikat, Walmart, yang akan meluncurkan layanan toko online di Jepang. Dikutip dari Reuters, toko online yang akan diluncurkan pada semester II 2018 itu khusus memenuhi kebutuhan rumah tangga sehari-hari. Ekspansi bisnis ini dilakukan Walmart melalui kerja sama dengan perusahaan e-commerce setempat, Rakuten Inc. Toko online yang akan diluncurkan itu khusus memenuhi kebutuhan rumah tangga sehari-hari.Industri ritel merupakan industri yang strategis dalam perkembangan perekonomian di Indonesia. Potensi pasar Indonesia yang cukup 
besar menjadi salah satu faktor pendukung terus berkembangnya industri ritel di negeri ini. Dalam jangka waktu yang singkat, beberapa pelaku usaha ritel modern dengan kemampuan kapital yang luar biasa menghadirkan minimarket, supermarket, bahkan hypermarket yang kini bertebaran di setiap kota besar di Indonesia. Pertumbuhan supermarket mencapai $50 \%$ pertahun dan pada periode yang sama, hypermarket bahkan mencapai $70 \%$ pertahun. Pertumbuhan supermarket dan hypermarket yang terkesan ekspansif ini disebabkan karena konsep yang ditawarkan cukup diterima oleh masyarakat perkotaan di Indonesia. Konsumen dimanjakan dengan berbagai hal yang berkaitan dengan keamanan, kemudahan lokasi, kenyamanan, ruangan yang lebih luas, bersih dan menarik, variasi produk yang semakin beragam, kualitas produk yang terus meningkat dan tentu saja harga produk yang lebih murah.

Salah satu strategi yang marak dilakukan pengusaha ritel adalah pengembangan produk bermerek distributor atau pengecer (private label), yaitu produk yang mereknya didesain dan dikembangkan dengan nama pengecer bersangkutan dan hanya dijual oleh perusahaan tersebut. Misalnya Hypermart menjual produk makanan atau minuman dengan merek Hypermart juga. Merek mereka tidak sama dan tidak tergantikan dengan merek di toko lain. Produk private label dihadirkan untuk menambah pilihan belanja bagi konsumen. Sebagai contoh, tisu, minuman, gula, air mineral, garam, dan produk lainnya yang bersifat grosir.);

\section{KAJIAN LITERATUR}

Sopiah \& Syihabudhin, (2008: 174) mengatakan "Citra toko memiliki pengertian pandangan atau persepsi masyarakat terhadap nama atau produk toko secara efektif baik dari segi nilai, kualitas maupun harga. Penciptaan citra toko sangat penting karena berpengaruh terhadap perilaku konsumen. Jadi citra toko dari suatu tempat berbelanja menjadi penting bagi konsumen, karena konsumen umumnya lebih memilih pusat perbelanjaan yang memberikan citra yang baik pada mereka". Menurut London \& Bitta dalam Subagyo, (2014: 3) menyatakan indikator dari citra toko adalah sebagai berikut: Fasilitas fisik, barang dagangan, pelayanan, kenyamanan. Persepsi harga merupakan penilaian konsumen mengenai perbandingan besarnya pengorbanan dengan apa yang akan didapatkan dari produk atau jasa. Persepsi harga berkaitan dengan bagaimana informasi harga dipahami seluruhnya oleh konsumen dan memberikan makna yang dalam bagi mereka. Pendekatan untuk memahami persepsi harga adalah pemrosesan informasi. Jacoby \& Olson, (2000). Indikator diambil dari penelitian sebelumnya yang dilakukan oleh Diallo, (2012) sebagai berikut : Harga murah, harga terjangkau, harga sesuai kualitas, harga sesuai dengan manfaat.

Buchari, (2007: 139) mengatakan "Citra produk adalah persepsi seseorang terhadap seperangkat atribut baik berwujud maupun tidak berwujud". Citra produk dibangun agar menjadi postitif dimata publik, baik publik yang telah menggunakan produk itu maupun potential customer yang hendak dibidik agar mengkonsumsi produk tersebut. Nielsen, (2005) menjelaskan "Private label sebagai merek yang dijual di 
bawah nama pemilik merek dan dipromosikan oleh peritel dalam toko mereka". Indikator dari citra produk private label adalah sebagai berikut: kualitas produk, tampilan produk, desain produk, kemasan produk.

Menurut Ain \& Ratnasari, (2015) "Niat beli ulang merupakan tindakan pasca pembelian yang disebabkan oleh adanya kepuasan yang dirasakan konsumen atas produk yang telah dibeli atau dikonsumsi sebelumnya. Apabila produk tersebut telah memenuhi harapan konsumen, maka ia akan membeli kembali produk tersebut". Menurut Ferdinand, (2002: 129) menyatakan indikator dari niat beli adalah sebagai berikut: niat transaksional, niat referensial, niat preferensial, niat eksploratif.

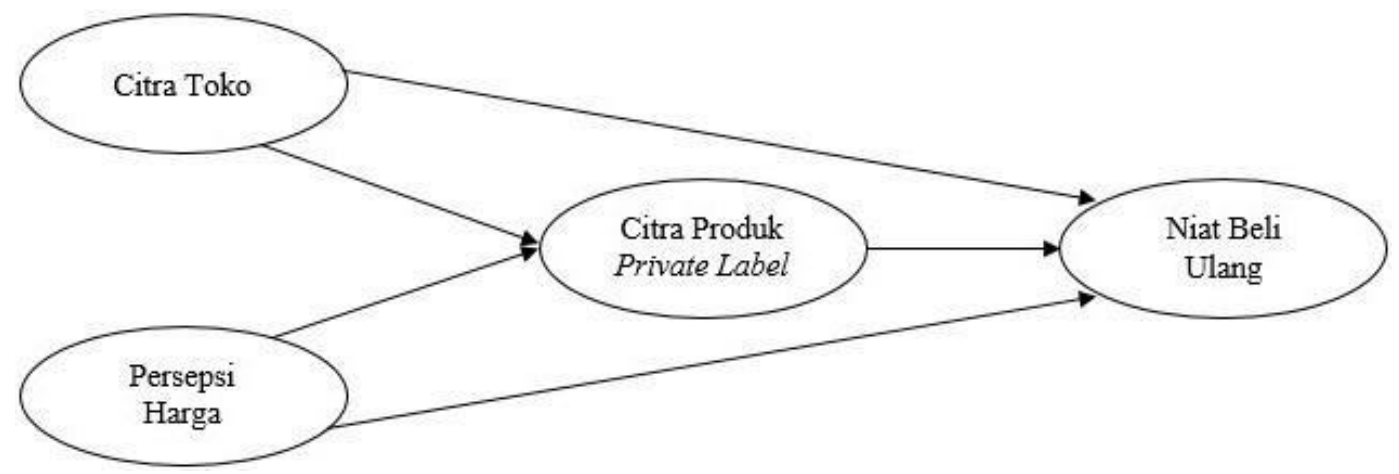

Gambar 1 Kerangka Penelitian

Dirumuskan hipotesis penelitian sebagai berikut:

$\mathrm{H}_{1}$ : Citra toko berpengaruh signifikan terhadap citra produk private label.

$\mathrm{H}_{2}$ : Persepsi harga berpengaruh signifikan terhadap citra produk private label.

$\mathrm{H}_{3}$ : Citra toko berpengaruh signifikan terhadap niat beli ulang.

$\mathrm{H}_{4}$ : Persepsi harga berpengaruh signifikan terhadap niat beli ulang.

H5: Citra produk private label berpengaruh signifikan terhadap niat beli ulang.

\section{METODE PENELITIAN}

Metode yang digunakan dalam penelitian ini adalah metode survei. Metode survei dengan kuesioner digunakan dalam pengumpulan data. Informasi dikumpulkan dari responden dengan menggunakan metode kuesioner, yaitu pengumpulan data yang dilakukan dengan menyebarkan pertanyaan atau pernyataan yang berhubungan dengan penelitian ini untuk memperoleh data berupa jawaban-jawaban dari para responden. Penelitian ini dilakukan pada Hypermart dan Indomaret di Kota Pontianak, yang dilakukan pada bulan Juli 2019 sampai Oktober 2019. Dalam penelitian ini digunakan data yang berbentuk angka (kuantitatif). Sumber data yang digunakan yaitu, data primer dan data sekunder. Teknik pengumpulan data menggunakan kuesioner dan wawancara. Uji Instrumen : Uji validitas dan uji reliabilitas, Uji Asumsi Klasik : Normalitas, multikolineralitas, heteroskedastisitas, autokorelasi, linearitas. Uji koefisien determinasi : path analysis. 


\section{HASIL DAN PEMBAHASAN}

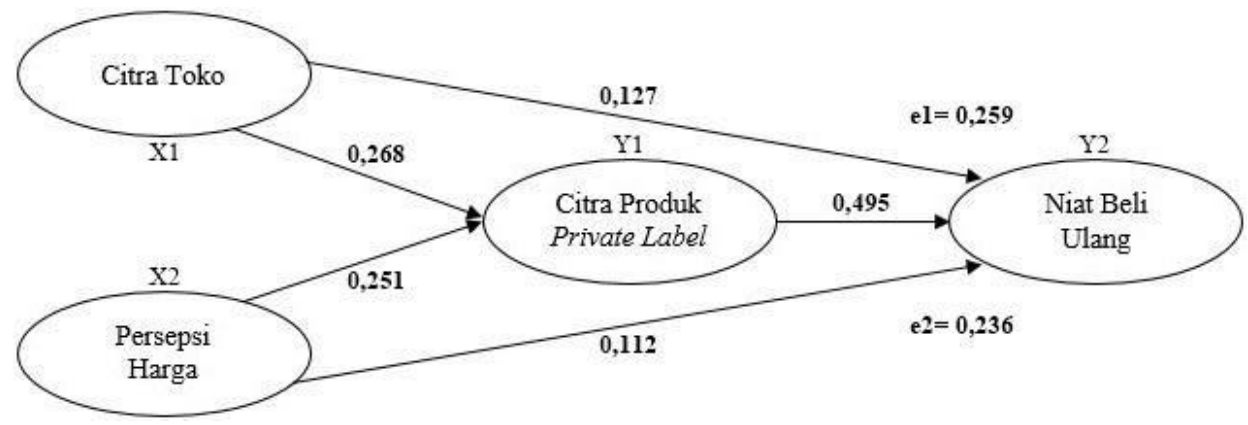

\section{Gambar 2 Diagram Hasil Analisis Jalur Pelanggan Hypermart}

Hasil pengaruh langsung dan tidak langsung pelanggan Hypermart menggunakan analisis jalur disajikan sebagai berikut:

1) Di ketahui pengaruh langsung yang diberikan $X 1$ terhadap $Y 2$ sebesar 0,127. Sedangkan pengaruh tidak langsung X1 melalui Y1 terhadap Y2 adalah perkalian antara nilai beta X1 terhadap Y1 dengan nilai beta Y1 terhadap Y2 yaitu: 0,268 $\mathrm{x}$ $0,495=0,132$. Maka pengaruh total yang diberikan X1 terhadap Y2 adalah pengaruh langsung ditambah dengan pengaruh tidak langsung yaitu: 0,127 +0,132=0,259. Berdasarkan hasil perhitungan di atas diketahui bahwa nilai pengaruh langsung sebesar 0,127 dan pengaruh tidak langsung sebesar 0,132 yang berarti bahwa nilai pengaruh tidak langsung lebih besar dibandingkan dengan nilai pengaruh langsung, hasil ini menunjukkan bahwa secara tidak langsung X1 melalui Y1 mempunyai pengaruh signifikan terhadap Y2.

2) Di ketahui pengaruh langsung yang diberikan $X 2$ terhadap $Y 2$ sebesar 0,112. Sedangkan pengaruh tidak langsung X2 melalui Y1 terhadap Y2 adalah perkalian antara nilai beta X2 terhadap Y1 dengan nilai beta Y1 terhadap Y2 yaitu: 0,251 x $0,495=0,124$. Maka pengaruh total yang diberikan X2 terhadap Y2 adalah pengaruh langsung ditambah dengan pengaruh tidak langsung yaitu: 0,112 +0,124=0,236 Berdasarkan hasil perhitungan di atas diketahui bahwa nilai pengaruh langsung sebesar 0,112 dan pengaruh tidak langsung sebesar 0,124 yang berarti bahwa nilai pengaruh tidak langsung lebih besar dibandingkan dengan nilai pengaruh langsung, hasil ini menunjukkan bahwa secara tidak langsung X2 melalui Y1 mempunyai pengaruh signifikan terhadap Y2. 


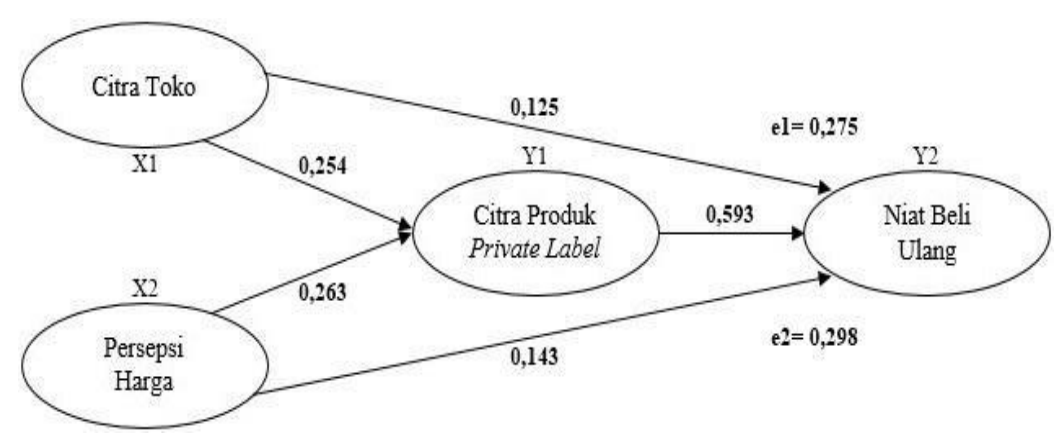

\section{Gambar 3 Diagram Hasil Analisis Jalur Pelanggan Indomaret}

Hasil pengaruh langsung dan tidak langsung pelanggan Indomaret menggunakan analisis jalur disajikan sebagai berikut:

1) Di ketahui pengaruh langsung yang diberikan $X 1$ terhadap $Y 2$ sebesar 0,125. Sedangkan pengaruh tidak langsung X1 melalui Y1 terhadap Y2 adalah perkalian antara nilai beta X1 terhadap Y1 dengan nilai beta Y1 terhadap Y2 yaitu: 0,254 $\mathrm{x}$ $0,593=0,150$. Maka pengaruh total yang diberikan X1 terhadap Y2 adalah pengaruh langsung ditambah dengan pengaruh tidak langsung yaitu: 0,125 +0,150=0,275. Berdasarkan hasil perhitungan di atas diketahui bahwa nilai pengaruh langsung sebesar 0,125 dan pengaruh tidak langsung sebesar 0,150yang berarti bahwa nilai pengaruh tidak langsung lebih besar dibandingkan dengan nilai pengaruh langsung, hasil ini menunjukkan bahwa secara tidak langsung X1 melalui Y1 mempunyai pengaruh signifikan terhadap Y2.

2) Di ketahui pengaruh langsung yang diberikan $X 2$ terhadap $Y 2$ sebesar 0,143. Sedangkan pengaruh tidak langsung X2 melalui Y1 terhadap Y2 adalah perkalian antara nilai beta X2 terhadap Y1 dengan nilai beta Y1 terhadap Y2 yaitu: 0,263 x $0,593=0,155$. Maka pengaruh total yang diberikan X2 terhadap Y2 adalah pengaruh langsung ditambah dengan pengaruh tidak langsung yaitu: 0,143 +0,155=0,298. Berdasarkan hasil perhitungan di atas diketahui bahwa nilai pengaruh langsung sebesar 0,143 dan pengaruh tidak langsung sebesar 0,155 yang berarti bahwa nilai pengaruh tidak langsung lebih besar dibandingkan dengan nilai pengaruh langsung, hasil ini menunjukkan bahwa secara tidak langsung X2 melalui Y1 mempunyai pengaruh signifikan terhadap Y2.

\section{PEMBAHASAN}

Pengaruh citra toko terhadap citra produk private label pada pelanggan Hypermart dan Indomaret

Diperoleh nilai signifikansi citra toko Hypermart sebesar 0,034 dan Indomaret sebesar 0,021 . Terdapat pengaruh signifikan citra toko terhadap citra produk private label pelanggan Hypermart dan Indomaret Kota Pontianak karena nilai signifikansi < 0,05 maka dari itu hasil hipotesis pertama diterima.

Pengaruh persepsi harga terhadap citra produk private label pada pelanggan Hypermart dan Indomaret

*corresponding authors e-mail : rony jusfarani@yahoo.com Online ISSN: 2721-4230 | Print ISSN: 2721-4281 DOI http://dx.doi.org/10.26418/ejme.v8i2.39807 
Diperoleh nilai signifikansi persepsi harga Hypermart sebesar 0,045 dan Indomaret sebesar 0,000 . Terdapat pengaruh signifikan persepsi harga terhadap citra produk private label pelanggan Hypermart dan Indomaret Kota Pontianak karena nilai signifikansi $<0,05$ maka dari itu hasil hipotesis pertama diterima.

Pengaruh citra toko terhadap niat beli ulang pada pelanggan Hypermart dan Indomaret

Diperoleh nilai signifikansi citra toko Hypermart sebesar 0,010 dan Indomaret sebesar 0,043 . Terdapat pengaruh signifikan citra toko terhadapniat beli ulang pelanggan Hypermart dan Indomaret Kota Pontianak karena nilai signifikansi < 0,05 maka dari itu hasil hipotesis pertama diterima.

Pengaruh persepsi harga terhadap niat beli ulang pada pelanggan Hypermart dan Indomaret

Diperoleh nilai signifikansi persepsi harga Hypermart sebesar 0,008 dan Indomaret sebesar 0,006. Terdapat pengaruh signifikan persepsi harga terhadap niat beli ulang pelanggan Hypermart dan Indomaret Kota Pontianak karena nilai signifikansi < 0,05 maka dari itu hasil hipotesis pertama diterima.

Pengaruh citra produk private label terhadap niat beli ulang pada pelanggan Hypermart dan Indomaret

Diperoleh nilai signifikansi citra produk private label Hypermart sebesar 0,025 dan Indomaret sebesar 0,055 . Terdapat pengaruh signifikan citra produk private label terhadap niat beli ulang pelanggan Hypermart Kota Pontianak karena nilai signifikansi $<0,05$ maka dari itu hasil hipotesis pertama diterima. Namun citra produk private label Indomaret menunjukkan nilai signifikansi $>0,05$ maka hasil hipotesis kelima Indomaret ditolak.

\section{SIMPULAN}

Berdasarkan hasil pengujian dan analisis, dapat disimpulkan sebagai berikut:

a. Analisis pengaruh citra toko terhadap citra produk private label pada pelanggan Hypermart: dari analisis diperoleh nilai signifikansi X1 sebesar 0,034 < 0,05. Sehingga dapat disimpulkan bahwa secara langsung terdapat pengaruh signifikan X1 terhadap Y1. Artinya semakin baik citra toko maka akan menyebabkan meningkatnya citra produk private label yang ditawarkan di Hypermart.

b. Analisis pengaruh persepsi harga terhadap citra produk private label pada pelanggan Hypermart: dari analisis diperoleh nilai signifikansi X2 sebesar 0,045< 0,05. Sehingga dapat disimpulkan bahwa secara langsung terdapat pengaruh signifikan X2 terhadap Y1. Artinya semakin baik persepsi harga maka akan menyebabkan meningkatnya citra produk private label yang ditawarkan di Hypermart.

c. Analisis pengaruh citra toko terhadap niat beli ulang pada pelanggan Hypermart: dari analisis diperoleh nilai signifikansi X1 sebesar 0,010<0,05. Sehingga dapat disimpulkan bahwa secara langsung terdapat pengaruh signifikan X1 terhadap 
Y2. Artinya semakin baik citra toko maka akan menyebabkan meningkatnya niat beli ulang produk private label yang ditawarkan di Hypermart.

d. Analisis pengaruh persepsi harga terhadap niat beli ulang pada pelanggan Hypermart: dari analisis diperoleh nilai signifikansi X2 sebesar 0,008 $<0,05$. Sehingga dapat disimpulkan bahwa secara langsung terdapat pengaruh signifikan X2 terhadap Y2. Artinya semakin baik persepsi harga maka akan menyebabkan meningkatnya niat beli ulang produk private label yang ditawarkan di Hypermart.

e. Analisis pengaruh citra produk private label terhadap niat beli ulang pada pelanggan Hypermart: dari analisis diperoleh nilai signifikansi Y1 sebesar 0,025 $<0,05$. Sehingga dapat disimpulkan bahwa secara langsung terdapat pengaruh signifikan Y1 terhadap Y2. Artinya semakin baik citra produk private label maka akan menyebabkan meningkatnya niat beli ulang produk private label yang ditawarkan di Hypermart.

f. Diketahui pengaruh langsung yang diberikan X1 terhadap Y2 sebesar 0,127. Sedangkan pengaruh tidak langsung X1 melalui Y1 terhadap Y2 adalah perkalian antara nilai beta X1 terhadap Y1 dengan nilai beta Y1 terhadap Y2 yaitu: 0,268 $\mathrm{x}$ $0,495=0,132$. Maka pengaruh total yang diberikan X1 terhadap Y2 adalah pengaruh langsung ditambah dengan pengaruh tidak langsung yaitu: 0,127 + $0,132=0,259$. Berdasarkan hasil perhitungan di atas diketahui bahwa nilai pengaruh langsung sebesar 0,127 dan pengaruh tidak langsung sebesar 0,132 yang berarti bahwa nilai pengaruh tidak langsung lebih besar dibandingkan dengan nilai pengaruh langsung, hasil ini menunjukkan bahwa secara tidak langsung X1 melalui Y1 mempunyai pengaruh signifikan terhadap Y2.

g. Diketahui pengaruh langsung yang diberikan X2 terhadap Y2 sebesar 0,112. Sedangkan pengaruh tidak langsung X2 melalui Y1 terhadap Y2 adalah perkalian antara nilai beta X2 terhadap Y1 dengan nilai beta Y1 terhadap Y2 yaitu: 0,251 x $0,495=0,124$. Maka pengaruh total yang diberikan X2 terhadap Y2 adalah pengaruh langsung ditambah dengan pengaruh tidak langsung yaitu: 0,112+ $0,124=0,236$. Berdasarkan hasil perhitungan di atas diketahui bahwa nilai pengaruh langsung sebesar 0,112 dan pengaruh tidak langsung sebesar 0,124 yang berarti bahwa nilai pengaruh tidak langsung lebih besar dibandingkan dengan nilai pengaruh langsung, hasil ini menunjukkan bahwa secara tidak langsung X2 melalui Y1 mempunyai pengaruh signifikan terhadap Y2.

h. Analisis pengaruh citra toko terhadap citra produk private label pada pelanggan Indomaret: dari analisis diperoleh nilai signifikansi X1 sebesar 0,021<0,05. Sehingga dapat disimpulkan bahwa secara langsung terdapat pengaruh signifikan X1 terhadap Y1. Artinya semakin baik citra toko maka akan menyebabkan meningkatnya citra produk private label yang ditawarkan di Indomaret.

i. Analisis pengaruh persepsi harga terhadap citra produk private label pada pelanggan Indomaret: dari analisis diperoleh nilai signifikansi X2 sebesar 0,000 $<0,05$. Sehingga dapat disimpulkan bahwa secara langsung terdapat pengaruh signifikan X2 terhadap Y1. Artinya semakin baik persepsi harga maka akan 
menyebabkan meningkatnya citra produk private label yang ditawarkan di Indomaret.

j. Analisis pengaruh citra toko terhadap niat beli ulang pada pelanggan Indomaret: dari analisis diperoleh nilai signifikansi X1 sebesar 0,043<0,05. Sehingga dapat disimpulkan bahwa secara langsung terdapat pengaruh signifikan X1 terhadap Y2. Artinya semakin baik citra toko maka akan menyebabkan meningkatnya niat beli ulang produk private label yang ditawarkan di Indomaret.

k. Analisis pengaruh persepsi harga terhadap niat beli ulang pada pelanggan Indomaret: dari analisis diperoleh nilai signifikansi X2 sebesar 0,006 0,05. Sehingga dapat disimpulkan bahwa secara langsung terdapat pengaruh signifikan X2 terhadap Y2. Artinya semakin baik persepsi harga maka akan menyebabkan meningkatnya niat beli ulang produk private label yang ditawarkan di Indomaret.

1. Analisis pengaruh citra produk private label terhadap niat beli ulang pada pelanggan Indomaret: dari analisis diperoleh nilai signifikansi Y1 sebesar 0,055 $<0,05$. Sehingga dapat disimpulkan bahwa secara langsung tidak terdapat pengaruh signifikan Y1 terhadap Y2. Artinya citra produk private label belum mampu membuat konsumen melakukan niat beli ulang produk private label yang ditawarkan di Indomaret.

m. Diketahui pengaruh langsung yang diberikan X1 terhadap Y2 sebesar 0,125. Sedangkan pengaruh tidak langsung X1 melalui Y1 terhadap Y2 adalah perkalian antara nilai beta X1 terhadap Y1 dengan nilai beta Y1 terhadap Y2 yaitu: 0,254 x $0,593=0,150$. Maka pengaruh total yang diberikan X1 terhadap Y2 adalah pengaruh langsung ditambah dengan pengaruh tidak langsung yaitu: 0,125 + $0,150=0,275$. Berdasarkan hasil perhitungan di atas diketahui bahwa nilai pengaruh langsung sebesar 0,125 dan pengaruh tidak langsung sebesar 0,150 yang berarti bahwa nilai pengaruh tidak langsung lebih besar dibandingkan dengan nilai pengaruh langsung, hasil ini menunjukkan bahwa secara tidak langsung X1 melalui Y1 mempunyai pengaruh signifikan terhadap Y2.

n. Diketahui pengaruh langsung yang diberikan X2 terhadap Y2 sebesar 0,143. Sedangkan pengaruh tidak langsung X2 melalui Y1 terhadap Y2 adalah perkalian antara nilai beta X2 terhadap Y1 dengan nilai beta Y1 terhadap Y2 yaitu: 0,263 x $0,593=0,155$. Maka pengaruh total yang diberikan X2 terhadap Y2 adalah pengaruh langsung ditambah dengan pengaruh tidak langsung yaitu: 0,143+ $0,155=0,298$. Berdasarkan hasil perhitungan di atas diketahui bahwa nilai pengaruh langsung sebesar 0,143 dan pengaruh tidak langsung sebesar 0,155 yang berarti bahwa nilai pengaruh tidak langsung lebih besar dibandingkan dengan nilai pengaruh langsung, hasil ini menunjukkan bahwa secara tidak langsung X2 melalui Y1 mempunyai pengaruh signifikan terhadap Y2.

\section{REKOMENDASI}

Rekomendasi dari penelitian ini adalah sebagai berikut:

a. Citra toko dan persepsi harga berpengaruh terhadap citra produk private label, oleh karena itu Hypermart Kota Pontianak harus tetap menjaga dan 
meningkatkan citra toko, karena citra toko menjadi kesan nyata dan paling awal yang diperoleh konsumen. Penting bagi Hypermart untuk menjaga konsistensi dalam menentukan kebijakan harga yang sesuai dengan kualitas produk yang diberikan. Sehingga dapat mendorong niat konsumen untuk membeli ulang produk private label-nya.

b. Citra toko dan persepsi harga berpengaruh terhadap niat beli ulang, oleh sebab itu Hypermart Kota Pontianak diharapkan tetap memperhatikan dan mengembangkan aspek-aspek pada citra toko dan persepsi harga yang dapat memicu niat membeli ulang konsumen.

c. Citra produk private label berpengaruh terhadap niat beli ulang, oleh karena itu Hypermart Kota Pontianak diharapkan terus mengembangkan desain/bentuk kemasan produk private label agar terlihat lebih variatif dan inovatif dimata konsumen.

d. Citra toko dan persepsi harga berpengaruh terhadap citra produk private label, oleh karenanya Indomaret Kota Pontianak diharapkan tetap mempertahankan citra toko yang positif agar mampu memberikan kepuasan pada konsumen. Penting juga bagi Indomaret untuk menjaga kestabilan harga pada produk private label yang dijual agar dapat bersaing dalam industri ritel yang semakin kompetitif.

e. Citra toko dan persepsi harga berpengaruh terhadap niat beli ulang pada pelanggan Indomaret Kota Pontianak, hal ini membuktikan bahwa konsumen merasa loyal terhadap produk private label Indomaret dikarenakan perusahaan mampu memberikan kenyamanan saat berbelanja dan harga produknya yang ekonomis dan terjangkau.

f. Sedangkan untuk citra produk private label tidak berpengaruh terhadap niat beli ulang pada pelanggan Indomaret Kota Pontianak. Mengingat sangat pentingnya niat beli ulang, maka perusahaan harus dapat meyakinkan konsumen dengan citra produk private label yang positif seperti menciptakan desain kemasan produk yang menarik dan dapat bersanding dengan produk-produk nasional sehingga niat beli ulang konsumen Indomaret meningkat.

\section{DAFTAR PUSTAKA}

Ailawadi. K.L., Keller, K.L. (2004). Understanding Retail Branding: Conceptual Insights and Research Priorities. Journal of Retailing Vol.80, No.4:331-342.

Ain, Nurul \& Ririn, Tri Ratnasari. (2015). Pengaruh Citra Merek Melalui Sikap Konsumen Terhadap Niat Beli Ulang pada Produk Busana Muslim Zoya di Surabaya. JESTT, 2 (7), h: 1-17.

Amador, Abror Aflah. (2012). Pengaruh Kualitas Produk dan Kualitas Pelayanan Terhadap Sikap Konsumen dan Implikasinya Terhadap Minat Beli Ulang (Studi Kasus pada Semerbak Coffee Tembalang Semarang). Skripsi Fakultas Ekonomi dan Bisnis Universitas Diponegoro Semarang. 
Augusty, Ferdinand. (2006). Metode Penelitian Manajemen: Pedoman Penelitian untuk Skripsi, Tesis dan Disertasi Ilmu Manajemen. Universitas Diponegoro Semarang.

Buchari, Alma. (2007). Manajemen Pemasaran dan Pemasaran Jasa. Edisi Revisi. CV. Alfabeta, Bandung

Diallo, Mbaye.F. (2012). Effects of Store Image and Strore Brand Price-Image on Store Brand Purchase Intention: Apllication to an Emerging Market. Journal of Retailing Consumer Sarvices, 19, 360-367.

Ghozali, Imam. (2005). Aplikasi Analisis Multivariate dengan SPSS. Badan Penerbit Universitas Diponegoro, Semarang.

Ghozali, Imam. (2006). Aplikasi Analisis Multivarite dengan SPSS. Cetakan Keempat, Badan Penerbit Universitas Diponegoro, Semarang.

Kotler, Philip, \& Garry Armstrong. (2008). Prinsip-prinsip Pemasaran. Jilid 1, Erlangga, Jakarta.

Kuncoro, Mudrajad. (2009). Metode Riset untuk Bisnis dan Ekonomi. Penerbit Erlangga, Jakarta.

Levy \& Weitz. (2007). Retail Management. 6th Edition. United States of America: McGraw-Hill International.

Nazir, Moh. (2005). Metode Penelitian. Ghalia Indonesia, Jakarta.

Priyatno, Duwi. (2011). Buku Saku Analisis Statistik Data. Penerbit MediaKom. Yogyakarta.

Santoso, Singgih. (2009). Panduan Lengkap Menguasai Statistik Dengan SPSS. Jakarta: PT. Elex Media Komputindo.

Schiffman \& Kanuk. (2007). Perilaku Konsumen. Edisi Kedua. Jakarta: PT. Indeks Gramedia.

Sekaran, Uma. (2011). Research Methods for Business (Metode Penelitian untuk Bisnis). Jakarta: Salemba Empat.

Sopiah \& Syihabudhin. (2008). Manajemen Bisnis Ritel. Yogyakarta: Penerbit Andi.

Subagyo, Ahmad. (2014). Manajemen Koperasi Simpan Pinjam. Jakarta: Mitra Wacana Media.

Sugiyono. (2013). Metode Penelitian Pendidikan Pendekatan Kuantitatif, Kualitatif dan R\&D. Bandung: Alfabeta.

Sugiyono. (2016). Metode Penelitian Kuantitatif, Kualitatif dan R\&D. Bandung: Alfabeta.

Wu, P. C., Yeh, G. Y.-Y., \& Hasio, C.-R. (2011). The Effect of Store Image and Service Quality on Brand Image and Purchase Intention. Australasian Marketing Journal, 30-39.

Yaqian, Z. (2011). The Impact of Costumer-Based Brand Equity on Revisit Intentions: An Empirical Study of Five Shanghai Budget Hotels. AU-GSB eJournal (Online) Vol. 4, No. 1.168-181. 